\title{
Assessment of the Economic and Social Impact Using SROI: An Application to Sport Companies
}

\author{
Giovanni Lombardo ${ }^{1, *(\mathbb{C})}$, Andrea Mazzocchetti ${ }^{1}$, Irene Rapallo ${ }^{2}$, Nader Tayser ${ }^{2}$ and \\ Silvano Cincotti ${ }^{1}$ \\ 1 DIME, University of Genoa, 16145 Genoa, Italy \\ 2 DIME, University Spin Off SIGMA NL, 16145 Genoa, Italy \\ * Correspondence: giovanni.lombardo@unige.it
}

Received: 29 May 2019; Accepted: 28 June 2019; Published: 1 July 2019

check for updates

\begin{abstract}
This paper evaluates the social impact of a football club and its philanthropic organization on the local community and its stakeholders, namely supporters, sponsors, players, and shopkeepers. The methodology used is the Social Return on Investment (SROI). SROI methodology includes all the beneficiaries that are beyond the scope of the company's accounting and its fiscal and financial statements. The aim is to assess both the benefits and the negative impacts of a company's activities on stakeholders. This type of analysis combines the use of qualitative, quantitative and financial information gathered and analyzes them in order to estimate the amount of "value", including mental health and well-being, created or destroyed by a business activity, by a project or by the overall operation of an organization. The sport club under review in the present analysis is called Virtus Entella, an Italian football club playing in the second division. An SROI indicator was applied in reference to the business activity that took place during the championship season 2017/2018. Results show that the social impact created during the championship amounts to approximately 44 million Euro against a financial investment of 15 million Euro, producing an SROI ratio of 2.98:1. This outcome suggests that for every euro invested by the football club, about 3 Euros of social value is created.
\end{abstract}

Keywords: corporate social responsibility; social return on investment; social impact; theory of change; SROI; football; soccer; sport

\section{Introduction}

During the last decades of the 20th century, Corporate Social Responsibility (CSR) became a crucial aspect of corporate management, mainly due to an enhanced awareness by the private sector of their social and environmental impact, led by the evolution of labor unions, the increase in consumer power and the assumption by governments of more responsibility for welfare [1].

Notwithstanding its multifaceted definitions and approaches that have continued to evolve since the 1950s [2-4], we can refer to CSR as a movement aimed at encouraging companies to be more aware of the impact of their business on society and environment [5]. CSR integrates social and environmental principles in private companies' operations [6,7], while taking into due account stakeholders' expectations.

Corporations that actively engage in CSR aim at evaluating all of the outcomes of their activities, including welfare. However, an objective and encompassing evaluation represents a difficult challenge, since welfare is a broad concept that includes both tangible and intangible elements varying over time. Its assessment in monetary terms requires one to resort to proxies which pose the question of evaluation accuracy. 
There is a vast interest and a growing need for a management tool able to measure the welfare effects of CSR activities and to guide companies towards socially positive investments [8]. To this end, different organizations and academic institutions developed several social impact evaluation methods that are currently used by enterprises and the public sector for social value measurement. A list of the main social impact assessment tools includes: Social Enterprise Balanced Scorecard (BSC); Third sector performance dashboard; Ongoing assessment of social impact (OASIS); Social Return Assessment (SRA); Social Accounting and Auditing (SAA); Social Impact Measurement for Local Economies (SIMPLE); Benefit-Cost ratio; Social Return on Investment (SROI); Social e-valuator; Basic Efficiency Resource analysis (BER); Best Available Charitable Option Ratio (BACO); Cost per impact; Expected Return. See also $[9,10]$. Among them, SROI represents one of the most established social impact assessment methods, being an indicator that satisfies the main essential requirements of social impact evaluations, namely [11]: (i) The ability to measure outcomes rather than tracking output; (ii) The ability to compare the value of different types of benefits; (iii) The consideration of counterfactual evidence in impact creation; (iv) The ability to guide towards effective and coherent funding decisions.

In recent years, the use of SROI has been extending over new fields, e.g., health and social care, humanitarian initiatives, cultural activities and museums, rural development, environmental sustainability and sport activity. The latter is increasingly considered a way to promote values such as solidarity, respect, team spirit, cooperation and fair play.

In Italy, football is the most popular sport, both at a professional and an amateur level. The feeling of belonging that unites many cities to their football team is able to stimulate the interest and attention of the local community.

In this study, we employed SROI methodology to evaluate the effects of a football team's activity on its stakeholders. To the best of our knowledge, this is one of the first papers that presents an application of SROI on a football club (for an example of a study of the social impact of a football club's activities, see [12]), which is receiving increasing attention by the Union of European Football Association (UEFA) through the promotion of SROI as a tool to evaluate the benefits of Football clubs on society (see [13]).

The organization analyzed is called Virtus Entella, an Italian football club based in the municipality of Chiavari playing in the national second division league.

An SROI indicator was applied with reference to both the outcomes generated on the local community (commercial and transport business) and the bio-psycho-social value made for the team and their families. Furthermore, the activity of "Entella nel Cuore", a philanthropic organization created by Virtus Entella, was taken into account since it is strictly linked with the football club's activity.

The methodology applied for the business case of Virtus Entella can be used for different sport clubs. Therefore, the framework presented in this work could be used for other sports' organizations.

The results obtained show that the social impact generated during the 2017/2018 championship amounts to approximately 44 million Euro against an investment of 15 million Euro, producing an SROI ratio of 2.98:1. Therefore, according to the outcomes, for every euro invested by the Virtus Entella, about 3 Euros of social value is created.

\section{Theoretical Background}

The rationale behind the SROI is that each investment should consider not only the financial value it produces, but also include a wider range of benefits. Such benefits are not considered by the main indicators employed in financial analysis, which account only for the financial value. One of the most popular indicators is the Return on Investment (ROI), which compares the gain or loss generated on an investment relative to the amount of money invested [14].

However, most of the business activities generate impacts that include other social, economic and environmental dimensions. 
In the field of economics, these effects are known as externalities. According to [15], externalities are action taken by consumers or producers that affect other consumers or producers, for which producers do not pay or consumers are not compensated.

Externalities can arise on the production and on the consumption side. They can be negative (for instance, air and water pollution, systemic risk, passive smoking) or positive (for instance, R\&D activities, individual education, vaccination) $[16,17]$.

The concept of externality was first discussed by Marshall and later on given an analytical framework by Pigou [18]. Pigou studied the divergence between marginal private interest and marginal social interest; Pigou proposed to set a tax system on polluting activities, believing that State intervention should correct negative externalities considered as market failures.

On the other hand, Coase pointed out that taxes and subsidies are not necessary if the people affected by the externality and the people creating it can bargain: in his theory, Coase assumes the possibility of well-defined property rights and zero transaction costs [19]. In particular, Coase's theorem states that if trade in an externality is possible and there are no transaction costs, bargaining will lead to an efficient outcome regardless of the initial allocation of property rights. In this way, the problem of externalities could be resolved by rational contracting by the interested parties.

However, in practice public and private parties often fail to resolve the problem of externalities on their own, mainly because externalities are difficult to measure. Therefore, social, environmental and community impacts frequently do not translate into numbers and reliable quantitative measurements.

The measurement of such impacts has been the focus of many studies, starting from the Economics of Welfare of Pigou, followed by the development of the cost-benefit analysis in 1950s [20,21] and by the creation of Environmental Impact Assessments and the rise of environmental economics in 1980s as a subject of study and analysis [22].

However, these studies and methodologies do not consider all the stakeholders in evaluating the social impact of an organization or an activity. Moreover, they include only quantified economic and financial data rather than considering unquantified social benefits, which can only be assessed by involving the relevant stakeholders.

To overcome these limitations, and with the aim of creating a reliable tool to evaluate unquantified social benefits, in the 1990s the New Economics Foundation (NEF) developed the SROI, a principle-based methodology that takes the financial return on investment a step further by accounting for social, environmental, and economic costs and benefits [23].

SROI also has its limitations: it leaves room for subjective perception and personal judgement while it allows for discretion in setting the indicators and quantifying the impact. This makes it possible to overclaim the value created and it may also lead to misunderstandings about how to interpret the SROI ratio.

However, it is worth remarking that the goal of SROI is not only to provide a numerical estimation of the social impact, but to help organizations (i) to understand the social value created by an activity, enabling them to make better informed decisions; (ii) to better connect with stakeholders in order to meet their expectations; (iii) to change management strategies according to well-defined goals.

In this study, we do not aim to provide a multipurpose framework for the measurement of all the impacts, but we focus on the quantitative and qualitative evaluation of the positive and negative intangible externalities created by sport clubs.

\section{Social Return on Investment}

To conduct the SROI, it is essential to understand the theory of change and how changes can be influenced through economic and social activities. Once this is understood, it becomes clear that social changes can also be measured.

Theory of Change (ToC) can be defined as "a tool and methodology to map out the logical sequence of an initiative from inputs to outcomes" [24]. It represents a comprehensive description of how and why a desired change is expected to happen in a certain context. ToC methodology defines long-term 
goals and then maps backward to identify necessary preconditions, or assumptions, that explain both the mini-steps that lead to the long-term goal and the connections between these activities and the outcomes of an intervention or program. For each step in the sequence, stakeholders outline clear indicators, thresholds, and assumptions.

ToC can be developed for different levels of activity, for instance an event, a project, a program, a policy, a strategy or an organization [25] and thus represents a rather important step within the SROI framework, providing the story of how stakeholders are involved in the project or activity and their perception and belief of how their lives have changed or will change.

The SROI methodology was firstly developed in 1996 by the Roberts Foundation, an organization of American philanthropy venture, in a pioneering report entitled "New Social Entrepreneurs: The Success, Lessons, and Challenge of Non-Profit Enterprise Creation" [26]. In the following years, the Roberts Foundation (under its new initiative, the Roberts Enterprise Development Fund or REDF) further increased its effort to create a meaningful methodology to calculate non-financial benefits [27].

In recent decades, the expansion of cooperatives, mutual societies, social enterprises and all direct volunteer activities $[28,29]$, increased the demand for impact assessment's tools, both to internally evaluate the social effects of activities thus improving the services, and to account for external funders and donors.

In this context, the interest in SROI has been growing and the efforts to improve its efficacy have been constantly evolving [30-35]. Nowadays, the SROI methodology is carried out worldwide by the Social Value International, a leading international network engaged in the social impact measurement, born from the merger of the SROI Network and Social Impact Analysis Information and currently encompassing members from 45 countries.

In general, the SROI methodology describes how change is being created, placing monetary value on that change and thus allowing to measure the value of social outcomes generated by an organization in relation to the relative cost of achieving those outcomes, i.e.:

$$
S R O I=\frac{\text { Net Present Value of Outcomes }}{\text { Net Present Value of Investment }}
$$

Social return on investment uses elements of social accounting and cost-benefit analysis [36], as the costs and the outcomes are quantified in monetary units and compared to evaluate the impact of an activity or intervention.

However, it is worth remarking that the SROI does not limit to express the financial value, but is intended to be an understandable way of expressing the creation of social value [37]. Therefore, SROI measurement should be combined with qualitative assessment of stakeholders' experience, to find meeting points between what an organisation and its stakeholders want to achieve, helping to increase social value and to create a dialogue with stakeholders that allows them to be effectively involved in the organization's activities.

The SROI methodology can be divided into two main categories as stated in [34], namely:

1. Evaluative, conducted retrospectively and based on actual outcomes that have already taken place.

2. Forecast, which predicts how much social value will be created if the activities meet their intended outcomes.

The application of the SROI encompasses a wide range of organisations across the public and private sectors, covering several fields. Among them are health and social care [38,39], humanitarian initiatives [40,41], cultural activities and museums [42,43], rural development [44,45], and environmental sustainability $[11,46]$.

Regarding the construction process of an SROI, it is important to define stages and to rigorously follow them. Table 1 provides a list and a description of each stage used to perform the analysis of this work, which comply with the main principles and standard of SROI methodology [34]. 
Table 1. Steps required by the Social Return on Investment (SROI) methodology.

\begin{tabular}{|c|c|}
\hline SROI Stage & Description \\
\hline $\begin{array}{l}\text { 1. Definition of the field of analysis, } \\
\text { identification and involvement of } \\
\text { the stakeholders. }\end{array}$ & $\begin{array}{l}\text { The stakeholders can all be the subjects that live the change or that are influenced by the } \\
\text { activity both positively and negatively. }\end{array}$ \\
\hline $\begin{array}{l}\text { 2. Construction of a Map of the Impact, } \\
\text { modelled through the involvement of } \\
\text { the stakeholders. }\end{array}$ & $\begin{array}{l}\text { The impact map describes how the analyzed activity uses certain resources (inputs) to } \\
\text { produce outputs that in turn will result in outcomes for stakeholders. }\end{array}$ \\
\hline $\begin{array}{l}\text { 3. Evidencing outcome identification } \\
\text { and assignment of a value. }\end{array}$ & $\begin{array}{l}\text { Stakeholders are fundamental in this stage, being those who have experienced a change. } \\
\text { They are also "heard" through qualitative approaches such as questionnaires, interviews or } \\
\text { "focus groups", in addition to quantitative data collection. } \\
\text { A monetary value is assigned to the outcomes through the identification of adequate } \\
\text { financial values that help demonstrate to a stakeholder the importance of the changes in } \\
\text { their experiential sphere. Therefore, this stage of the analysis involves the definition of } \\
\text { economic proxies for assets that often do not have a market value, also considering that for } \\
\text { some goods there is not an objective cost, but it is the result of the subjective perception of } \\
\text { those who use it. In this perspective, we used the methods of Contingent Valuation, such } \\
\text { as questionnaires, focus groups and stakeholders' interviews. }\end{array}$ \\
\hline \multirow{5}{*}{ 4. Calculation of the impact. } & $\begin{array}{l}\text { This phase is very important as it reduces the risk of overestimating the analysis carried } \\
\text { out, thus reporting the value of the impact as a real precautionary measure. } \\
\text { The calculation goes through four further steps (or a detailed description of the filters } \\
\text { coefficients in the SROI method see [47]): }\end{array}$ \\
\hline & $\begin{array}{l}\text { - Estimation of the deadweight. The deadweight is defined as the measure of the amount } \\
\text { of outcome that would have occurred even if the activity had not taken place. To } \\
\text { calculate it, we referenced to comparison groups. The relationship between } \\
\text { deadweight and outcome is reverse: as the deadweight increases, outcome decreases. } \\
\text { Estimation of the displacement. It indicates the displacement given by new negative } \\
\text { elements that overlap with pre-existing positive elements, even in neighboring } \\
\text { populations. It is also called "substitution effect", since it occurs when the externalities } \\
\text { determined by an intervention have negative effects not foreseen by the activity. }\end{array}$ \\
\hline & $\begin{array}{l}\text { - Estimation of the attribution. The attribution is the assessment of how much of the } \\
\text { outcome comes from the contribution of other organizations or people. } \\
\text { Estimation of the drop off. The drop off indicates the reduction of the impact } \\
\text { across time. }\end{array}$ \\
\hline & $\begin{array}{l}\text { With regards to the calculation of the impact, we compute the net present value of each } \\
\text { outcome } j \text { using the following formula: }\end{array}$ \\
\hline & $\begin{array}{l}\sum_{k=1}^{n}\left(\begin{array}{c}\text { Proxy } \\
\text { Finalcial }\end{array} \text { Outcome }_{j}\right) \times \frac{1}{1-\text { Deadw }_{j}} \times \frac{1}{1-\text { Attr }_{j}} \times \frac{1}{1-\text { Displ }_{j}} \times \frac{1}{1-\text { DropOff }_{j}} \times \frac{1}{(1+i)^{k}} \\
\text { where } n \text { represents the number of years and } i \text { represents the discount rate. }\end{array}$ \\
\hline 5. Calculation of the SROI Ratio. & $\begin{array}{l}\text { At this step, the value of the outcome in the future is estimated, and the Net Present Value } \\
\text { is calculated. The latter is computed discounting the sum of costs and benefits at a certain } \\
\text { discount rate. } \\
\text { SROI }=\frac{\text { Net Present Value of Outcomes }}{\text { Net Present Value of Investment }}\end{array}$ \\
\hline
\end{tabular}

\section{The Virtus Entella Business Case}

\subsection{Introduction}

Nowadays, sport tends to be considered not only a successful and far-reaching economic phenomenon, but, increasingly, the carrier of the spread of values such as solidarity, respect for others, team spirit, cooperation and fair play. In fact, institutions and private actors have been questioning the connecting role of sport and its potential impact in resolving the psychological and social problems connected to the lack of social bonds and the fragmentation that increasingly characterize modern societies. Therefore, participation in sport activities at various levels represents an actual opportunity for growth, strengthening the role of the individual in the community, fostering positive ties and integration.

The European Union has started to recognize the growing importance of sport and its role in the everyday life of European citizens, as a factor of integration, participation in social life, tolerance, acceptance of differences and respect for rules. In the complex world of sports, the greatest expectations of human and social promotion are placed on amateur sports. With reference to Italy, the most popular professional and amateur sport, due to factors mainly linked to history, tradition and national culture, is football (soccer). 
In fact, the feeling of belonging that unites many cities to their football team is able to stimulate the interest and attention of many, fans and non-fans. Modern society is losing the sense of community, belonging and emotional participation that represent the mutual commitment individuals build in order to nurture and realize common values and objectives. The enormous potential of football must be exploited to create social value with and within the community. It is necessary to develop community projects and social cohesion, to enhance the positive experiences, including emotional ones, to bring sports education to schools, to create partnerships with local non-profit organizations and, even more important, to positively engage for the benefit of the local community. In brief, it is necessary to integrate ethical responsibility among the objectives of sports clubs, providing companies with the tools to facilitate this process.

The decision of Virtus Entella's Board to generate a positive social impact, in addition to the economic one, stems from the Board's awareness of the social role that the company plays, willing to grow in a more ethical direction, aware of the positive impact of the educational, economic, cultural and philanthropic initiatives that every year can be promoted, financed and managed.

The Virtus Entella's Board approached the innovative methodology of Social Return on Investment to measure the social impact of its activity on its territory and, more specifically, on the different stakeholders, who have been afterwards involved in the surveys carried out.

Assuming that the main stakeholders are the sport "supporters", the criterion applied to select the football club was to compare the average utilization ratio of football stadiums in the Italian second division League "Serie B" (44.1\%) with the coefficient of the individual teams participating in the championship.

According to this criterion, we chose Virtus Entella since its coefficient differed from the median of only $4 \%$, against an average difference from the median of $14 \%$ (authors elaboration from data [48]).

In the process of assessing the economic and social impact of the Virtus Entella sport club, the SROI was specifically applied in reference to the business generated in the local community (commercial and transport sectors) in relation to:

- the matches played by the team in the stadium.

- the value of the bio-psycho-social well-being for the team players.

- the educational role carried out by coaches for the benefit of young players and their families as indirect beneficiaries.

It is worth remarking that the methodology applied for the business case of Virtus Entella football club can be used for every sport club. Therefore, we present a practical application of a framework that could serve for other sports' realities.

\subsection{SROI Applied to Virtus Entella Football Club}

The SROI analysis was performed over a period of about four months, in which the Virtus Entella staff worked with the team of the University of Genova, exchanging information and learning how to replicate the analysis by themselves in the future.

The SROI value obtained results from an "evaluative" analysis conducted ex post in 2018, based on costs already borne and on outcomes achieved or to be achieved. In terms of impact analysis, however, it is usual to carry out a "forecast" impact survey to estimate how much social value will be created if certain activities are implemented and if certain effects or outcomes happen.

In the evaluation analysis carried out, it is necessary to distinguish between the impacts on different stakeholders, which can be summarized as:

1. Internal impact: First Team Players; Youth Sector Players (Under-15); Coaches.

2. External impact: Local shopkeepers (bars, restaurants, shops, hotels, public and private urban transport, buses and taxis); fans and subscribers; families of the youth sector athletes; Municipality of Chiavari; Duferco Group; sponsors of the team and the beneficiaries of the philanthropic 
activities of "Entella nel Cuore" (See Appendix A for a detailed description of the stakeholders and their role).

The definition of the scope and the identification of the evaluation proxies used to capture the value created by the activities directly involved the Directive Board and external researchers.

The "inputs" included all the operating costs referred to in Entella's income statement, as well as the operating costs of "Entella nel Cuore" related to the payment of the tutors and the costs of the structures hosting the beneficiaries of the services. The amount of these inputs is approximately 15 million Euros.

Following a comparison with the management of the Virtus Entella football club, some groups of relevant stakeholders were identified:

1. Local Shopkeepers

2. Supporters

3. First Team

4. Under-15 Team

5. Youth Sector Coaches

6. Families

7. Trust-Technical Sponsor

8. Municipality of Chiavari (Club's headquarter)

9. Owner \& shareholders ("Duferco")

10. Philanthropic activity ("Entella nel Cuore")

The stakeholders were consulted through online interviews and questionnaires with the aim of identifying the economic, psychological and social impacts of a direct participation in the club's activities for players, coaches, and supporters. The analysis includes the indirect impact on other subjects, such as the team's families or local shopkeepers. Furthermore, the study takes into account subjects that collaborate with the football club, promoting their activities, like sponsors, the Municipality of Chiavari, "Entella nel Cuore" and the team's owner "Duferco Group".

The results obtained with the use of the survey guarantee the representativeness of the population analyzed, since they are a statistically representative sample with a 95\% confidence interval and an $8 \%$ margin of error. The sample analyzed also represents a different cluster ensuring a stratified sample.

Focus groups and privileged witnesses helped to identify many participants of the activities and their relative outcomes.

The topics investigated for each group are specified in Appendix A. In particular, regarding the questions aimed at understanding the psycho-social variables, we took as reference the eight domains constituting the so-called "Life-Effectiveness Questionnaire" (LEQ), a multidimensional measurement tool, generally used to quantify the effects of psycho-social intervention programs. This tool is based on elements related to the cognitive and emotional sphere of the individual (e.g., the concept of self, self-efficacy and coping strategies) which, as a whole, constitute the soft-skills necessary to achieve fulfilment in the personal, social and work environment. To date, several research studies have used the LEQ, which has gained increasing attention from the scientific society as a reliable tool for research and evaluation of intervention programs in the psycho-educational field [49,50].

To build the questions related to the psychological effects, this work considered the following "domains" of the LEQ:

- $\quad$ Time Management (TM)

- $\quad$ Social Competence (SO)

- Achievement Motivation (AM)

- Intellectual Flexibility (IF)

- $\quad$ Task Leadership (TL) 
- Emotional Control (EC)

- $\quad$ Active Initiative (AI)

- $\quad$ Self Confidence (SC)

The questions concerning these thematic areas were created from scratch or borrowed from other questionnaires, according to the needs of the survey, while the response options were constructed using Likert scales.

\section{Results}

The results of the social impact evaluation performed on Virtus Entella Football club show that the discounted impact generated during the 2017/2018 championship amounts to approximately 43.9 million Euro. The maximum duration of the effects considered is given by a time span of five years and the impact has been discounted at 3\%. The discount rate used is the Weighted Average Cost of Capital (WACC), considering $1 \%$ of inflation, $0 \%$ of risk-free rate and $2 \%$ of risk-premium.

The amount of investment that generated this impact was about 14.7 million Euro, producing an SROI ratio of 2.98:1. Therefore, it may be argued that, for every euro invested by the Virtus Entella, about 3 Euros are created.

In Table 2, the analysis has been disaggregated to highlight the outcomes and the impacts relative to each stakeholder, within the proxies used for their measurements (a detailed description of each stakeholder is provided in the Appendix A).

Table 2. Results of SROI analysis.

\begin{tabular}{|c|c|c|c|}
\hline Stakeholders & Assessed Outcomes & Proxy & Impact Amount (€) \\
\hline Shopkeepers & $\begin{array}{l}\text { - Revenue increase (hotels, transportation, } \\
\text { catering, other purchases) } \\
\text { - Improvement of soft skill } \\
\text { - Consolidation of tourists and } \\
\text { their habits } \\
\text { - Improvement of the attractiveness of } \\
\text { the city } \\
\text { - Workers performance improvement }\end{array}$ & $\begin{array}{l}\text { - } \quad \text { Cost of tourist services } \\
\text { Cost of a course for } \\
\text { strengthening soft skills or } \\
\text { team building }\end{array}$ & 451.332 \\
\hline $\begin{array}{l}\text { Home and away } \\
\text { Supporters }\end{array}$ & $\begin{array}{l}\text { Change of emotional and psychological } \\
\text { condition and relational skills }\end{array}$ & $\begin{array}{l}\text { Annual subscription to recreational } \\
\text { clubs, concerts, internet sites for } \\
\text { meetings }\end{array}$ & 27.156 .641 \\
\hline First team players & $\begin{array}{l}\text { Change of self-esteem, interpersonal skills } \\
\text { and football technique }\end{array}$ & $\begin{array}{l}\text { Cost of psychologist and football } \\
\text { master }\end{array}$ & 193.883 \\
\hline Under-15 players & $\begin{array}{l}\text { Change self-esteem, interpersonal skills and } \\
\text { self-management skills }\end{array}$ & $\begin{array}{l}\text { Psychologist sitting cost and annual } \\
\text { theater course }\end{array}$ & 451.543 \\
\hline Youth sector coaches & $\begin{array}{l}\text { Improvement of educational capacity and } \\
\text { relationships between society and family }\end{array}$ & $\begin{array}{l}\text { Cost of an educator for } \\
\text { psychoeducational support }\end{array}$ & 123.979 \\
\hline Families & $\begin{array}{l}\text { Change of children's physical condition, } \\
\text { health and emotional condition }\end{array}$ & $\begin{array}{l}\text { One-year course for teenage rowing, } \\
\text { specialized treatment course and } \\
\text { psychological sessions cost }\end{array}$ & 508.725 \\
\hline $\begin{array}{l}\text { Trust-Technical } \\
\text { Sponsor }\end{array}$ & $\begin{array}{l}\text { Improvement of the current image and } \\
\text { greater future attractiveness }\end{array}$ & Value of sponsorship & 2.167 .000 \\
\hline Municipality of Chiavari & Improvement of the city image & $\begin{array}{l}\text { Cost of advertising campaign for the } \\
\text { city of Chiavari }\end{array}$ & 8.557 .500 \\
\hline $\begin{array}{c}\text { Shareholders } \\
\text { (Owner Business Group) }\end{array}$ & Improved group image and greater visibility & $\begin{array}{l}\text { Sponsorship value and sales } \\
\text { improvement }\end{array}$ & 427.667 \\
\hline $\begin{array}{l}\text { Philanthropic activity } \\
\text { "Entella nel Cuore" }\end{array}$ & $\begin{array}{l}\text { - Improvement of emotional and } \\
\text { psychological condition } \\
\text { - } \quad \text { Improvement of the health condition } \\
\text { and quality of the stay } \\
\text { - } \quad \text { Moral development of the person }\end{array}$ & $\begin{array}{l}\text { - } \quad \text { Psychologist session cost } \\
\text { - } \quad \text { Cost of "hospice" bed per day } \\
\text { - Monthly dorm cost }\end{array}$ & 6.792 .803 \\
\hline TOTAL (not discounted) & & & 46.831 .073 \\
\hline
\end{tabular}


The chart in Figure 1 shows the impact percentage of each stakeholder group. According to the results, internal stakeholders (i.e., first team players, youth sector players and youth sector coaches) receive less benefits since their number is smaller compared with that of external stakeholders. However, in relative terms, internal stakeholders enjoy a greater benefit.

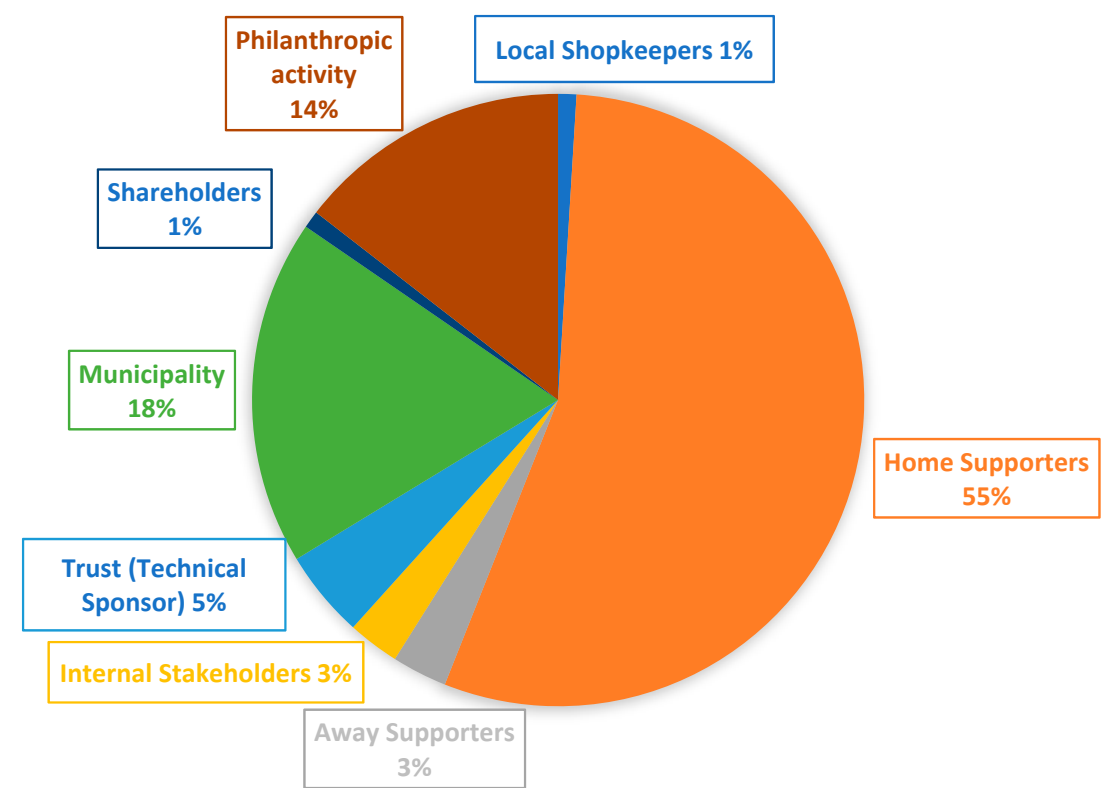

Figure 1. Summary of stakeholders' impact.

Although the methodology and the proxies can always apply, calculation (both in terms of numerical and structural data), should be reiterated and updated every year.

\subsection{Sensitivity Analysis}

We carried out a sensitivity analysis of the SROI based on the variation of different assumptions. The alternative scenarios enable the assessment of the SROI's sensitivity to the initial hypotheses and to the technical parameters' choice.

The sensitivity analysis carried out includes the change of two assumptions:

1. Including or not including the philanthropic activities ("Entella nel Cuore") within the SROI analysis.

2. The percentage of fans' attendance at the stadium in reference to the stadium's capacity. Moreover, the baseline estimations of $70 \%, 50 \%$ and $90 \%$ were tested.

The results are outlined in Table 3. The outcome of the analysis shows that the company creates positive social value in every scenario. Even in the most prudential case, i.e., without considering the philanthropic activities and with a half-empty stadium, an SROI with a ratio higher than 2:1 is produced. In the best case scenario, the company creates a social value that exceeds three times the value of the resources invested, close to the ratio of 4:1.

Table 3. Sensitivity analysis results.

\begin{tabular}{cccc}
\hline Scenario & Fans' Attendance & Philanthropic Activity ("Entella nel Cuore") & SROI \\
\hline Worst of worst & $50 \%$ & Not included & 2.09 \\
\hline Worst & $50 \%$ & Included & 2.51 \\
\hline Standard fans turnout, without philanthropic activity & $70 \%$ & Not included & 2.55 \\
\hline Standard fans turnout, with philanthropic activity & $70 \%$ & Included & 3.45 \\
\hline Top & $90 \%$ & Included & Included \\
\hline Top of top & $100 \%$ & 3.68 \\
\hline
\end{tabular}




\subsection{Control Group}

Nowadays, every scientific field recognizes the need to perform comparative analyses in order to validate results.

In this analysis, we compare the results obtained with those of another real football club, here called the "Comparison Club", which also has a youth sector and operates in a similarly sized territory to Virtus Entella. The comparison is made between two groups of people comparable by gender (male), age group (category Under-15) and context of origin (two medium-sized Ligurian cities) in order to assess more objectively the impact calculated for Virtus Entella.

For the Comparison Club's SROI calculation, we maintained the methodology and the framework used for the Virtus Entella. The financial proxies used for outcomes' evaluation and the groups of stakeholders involved are the same in both cases, with the exception of "Entella nel Cuore", since it is a characteristic philantropic activity of Virtus Entella.

The main differences concerning the size of stakeholders between Virtus Entella and the Comparison Club are:

- Local Shopkeepers: the number of local businesses (hotel, transport, taxi, bar, restaurant, stores) found on the territory of the Comparison Club is smaller. Moreover, the decentralized position of the stadium impacts on the number of customers.

- Supporters: the number of fans of the Comparison Club is smaller. The number of supporters considered corresponds to $30 \%$ of the total capacity of the stadium. Among them, only about $70 \%$ find an impact due to the team's activity.

- Technical Sponsor: the financial proxy used for the Comparison Club is lower than the one considered for Virtus Entella, because of the smaller company size.

The calculation of the SROI Ratio for the Comparison Club provides a result of 1.97:1, which is lower than the one obtained by Virtus Entella.

The main factors triggering this difference are:

- A systematic philanthropic activity

- Participation in a higher category league

- A more stable corporate structure.

\section{Conclusions}

This paper aims to contribute to the economic issue of externalities' evaluation, which has been debated in the economic literature since the beginning of the last century and still represents a controversial topic.

The methodology that we propose, namely the Social Return on Investment (SROI), represents a step forward with respect to the cost-benefit analysis since it directly involves the stakeholders, i.e., those who are affected by the considered activities, allowing an evaluation of externalities such as the intangible outcomes of an activity or an organization, taking into account not only the financial value produced, but also the social, economic and environmental dimensions.

Notwithstanding the SROI represents a leading tool for attempting to measure the impacts and added value of organizations or activities, it also presents limitations since it leaves a great deal of space for personal judgement and allows for discretion in setting the indicators and quantifying the impact. Although some standards are defined in the literature, they mostly regard the steps to conduct the SROI and not the numerical values to calculate the impact.

This work shows an application of the SROI to a football club, analyzing the impact that it can have on its stakeholders and on the community in terms of social value creation.

To measure the social value created, we employed the evaluative SROI methodology, applying it to Virtus Entella football club and its stakeholders (i.e., local shopkeepers, team supporters, the First Team, 
the Under-15 Team, Youth Sector Coaches, the team's families, Trust-Technical Sponsor, Municipality of Chiavari, Shareholders, and philanthropic activity_-"Entella nel Cuore").

Results suggest that the social impact made during the 2017/2018 championship amounts to approximately 44 million Euro against a financial investment of approximately 15 million Euro, producing an SROI ratio of 2.98:1. The sensitivity analysis shows that the outcome obtained is quite robust in terms of supporters' presence at the stadium and their active participation. Likewise, the influence of the social activities of "Entella nel cuore", the football club philanthropic association, has proved to be significant. Additionally, the results obtained in the "Virtus Entella" case were compared with those of another football club used as a control case, whose SROI was 1.97:1. The analysis shows that factors such as visibility, prestige at national level, appeal of the youth sector and the adoption of a value code of ethics, may increase the football club's positive impact on the local community and its stakeholders.

A further step to improve our work may be the inclusion of more football clubs, which would allow their outcomes to be compared, thus enriching our study.

Author Contributions: Conceptualization, G.L.; Data curation, G.L., I.R. and N.T.; Formal analysis, G.L.; Funding acquisition, G.L. and N.T.; Investigation, G.L.; Methodology, G.L., I.R., N.T. and S.C.; Project administration, G.L.; Software, G.L. and N.T.; Supervision, G.L. and S.C.; Validation, S.C.; Visualization, A.M.; Writing一original draft, G.L., A.M. and N.T.; Writing—review and editing, A.M.

Funding: This research received no external funding.

Acknowledgments: The authors acknowledge Rebecca Colombo, in collaboration with the SIGMA NL spin-off and start-up company of the University of Genoa; all Virtus Entella team and managers; the Duferco Group.

Conflicts of Interest: The authors declare no conflict of interest.

\section{Appendix A}

For each stakeholder analyzed, we provide a brief description of the impact assessment used for the calculation of SROI, highlighting the description of the outcomes, as well as the positive and negative effects of the sport activity.

\section{A.1. Local Shopkeepers}

\section{A.1.1. Description}

In reference to the assessment of the impact on the local business during the championship's home games played in Chiavari, the commercial activities taken into account were bars, restaurants/pizzerias, hotels and other accommodation facilities for fans (hotels, Airbnb, etc.), public and private urban transport, shops.

As far as the food and drink place such as "restaurants and pizzerias" are concerned, the assessment of the increase in the number of seats was differentiated between lunch and dinner, due to a different average expense between the two services.

All the impact assessments on this category of stakeholders were made with specific reference to the championship periods (August-May of each year taken into consideration). Therefore, the difference of expenditures was calculated based on the answers provided by the local retailers interviewed.

We used financial proxies and the estimation of costumers' average expenditure in order to quantify the expenditure on the following activities:

- Overnight in hotel/accommodation facilities

- Use of public transport-Bus

- Use of Taxies

- Amount of purchase in bars

- Amount of lunches served

- Amount of dinners served 
- General purchases in local shops

- Workers' development of "Soft skills"

An additional horizontal analysis in reference to the potential psychological effects resulting from the increase in customers during the matches played by Virtus Entella was carried out. Here the assumption is that, as the number of customers increases workload and stress in the undertaking of the business activities, retailers and their employees improve their coping and relational skills in order to execute their tasks.

These are not technical skills specific of one's professional role, but are social skills, such as communication, goal orientation, time management and stress. To deepen this topic and to investigate this theoretical hypothesis, an ad hoc question was inserted into the questionnaires built for this category of stakeholders.

\section{A.1.2. Positive Externalities and Outcomes}

Data collected show that, during the time under review, 30\% of interviewed retailers recorded an average sales growth that overall is equal to $13.8 \%$ per month. The duration of the effect was cautiously estimated for one year. An exception is the outcome linked to soft skills since they, once acquired, are considered to last for at least the following three years.

\section{A.1.3. Negative Externalities and Impacts}

- Deadweight: $0 \%$, because the customers' increase would not have been recorded in the absence of football matches;

- Displacement: $10 \%$, considering the negative externality, emerged from the interviews with the stakeholders, resulting from the ban on the sale of alcohol in glass containers during the games, provided by a municipal ordinance;

- Attribution: $0 \%$ for each outcome because no other comparable activities were identified for the influx of people on the same territory;

- Drop off: $0 \%$ because we considered the duration of each outcome limited to the year 2017/2018, except in the case of the psychological outcome (soft skills) that was set at $10 \%$.

\section{A.2. Supporters}

Supporters were divided into two distinct groups: supporters who attend home games and those who follow the team in its away games.

\section{A.2.1. Home Supporters}

\section{A.2.1.1. Description}

Home supporters are an integral part of the competitive game, due to their active participation, mainly emotional, in football games. Being relevant stakeholders, a questionnaire was designed for supporters, with the aim of identifying the average expenses that each supporter willingly meets when attending football matches, home and away. We also assessed the psychological motivations that push supporters to follow the championship (i.e., leisure time with friends, feeling of belonging, feeling of belonging to the local community, and opportunity to socialize).

The outcomes identified and quantified through the financial proxies are the following:

- Opportunity for recreation with their loved ones

- Opportunity for participation in community life

- Occasion for socialization

Given the maximum capacity of the stadium (5535 seats), we assumed an average attendance of $70 \%$, equal to 3875 seats taken per event. 
However, according to our questionnaire, not all the supporters declared to having been impacted by the club's activities. In particular, from the data obtained, it emerges that only $66 \%$ of the interviewed fans experienced an impact that was ascribed to the activity of Virtus Entella. Thus, the effective percentage of fans considered ( $46 \%$ ) is consistent with the average utilization ratio of Entella's football stadium $(44,1 \%)$.

\section{A.2.1.2. Positive Externalities and Outcomes}

The duration of the effect was estimated to last for a year, except for the improvement of the interpersonal skills that, as already highlighted, persist over time (in this case, it was estimated that it would last five years).

\section{A.2.1.3. Negative Externalities and Impacts}

- Deadweight: $5 \%$ because there are alternative opportunities for leisure/socialization/participation in city life, other than those related to the activity of the team;

- Displacement: $5 \%$, considering the problems of public order that the influx of people at the stadium could cause;

- Attribution: $0 \%$ for each outcome, because no other agent contributes to the occurrence of these effects;

- Drop off: $0 \%$, because we considered the duration of each outcome limited to the year 2017/2018, except in the case of outcomes linked to the possibility of socialization whose effects, presumably, last over time $(20 \%)$.

\section{A.2.2. Away Supporters}

\section{A.2.2.1. Description}

The impact of this category on our assessment was the same as the Home Supporters for the outcomes, but differs from them for the value of the proxies and the number of fans taken into consideration (an average of 120 spectators per event).

\section{A.2.2.2. Positive Externalities and Outcomes}

Keeping the same proxies, their value doubled, as the benefit following the team in a trip away from home was also considered to double.

\section{A.2.2.3. Negative Externalities and Impacts}

- Deadweight: $10 \%$, because, in addition to the opportunities for relax and socialization other than those related to the activity of the football team, the pollution produced to reach distant destinations was also considered.

- Displacement: 5\%, considering that the benefits measured here were not at the expense of other activities, except for the use of the police force to guarantee the public order.

- Attribution: $0 \%$ for each outcome, because no other agent contributes to the occurrence of these effects.

- Drop off: $0 \%$, because we considered the duration of each outcome limited to the year 2017/2018, except in the case of outcomes linked to the possibility of socialization whose effects, presumably, last over time $(20 \%)$. 


\section{A.3. First Team}

\section{A.3.1. Description}

The players of the first team are the soul of the company itself, as well as the core of its activities. The questionnaire they had to complete was conceived as a self-assessment on personal satisfaction related to their job.

Specifically, the outcomes considered and monetized through financial proxies are the following:

- Personal/professional satisfaction

- Change in family and friendship relationships.

- Change in future professional prospects

\section{A.3.2. Positive Externalities and Outcomes}

The answers provided show that $80 \%$ of the athletes experienced impacts that are to be ascribed to the Virtus Entella's activity. The duration of the effect was estimated to last from three to five years, since it is assumed that the experience of playing in this team creates added value in terms of relationships, personal and professional, whose effects can last over time.

\section{A.3.3. Negative Externalities and Impacts}

- Deadweight: 10\% for "personal satisfaction" and "social relationships", because the improvements in these areas of life are also linked to other factors and experiences. For the added value to their professional curriculum, no comparable experiences were identified $(0 \%)$.

- Displacement: $5 \%$, due to the stress deriving from competing in a professional category and to the time that this can subtract from family life, also considering that many players come from other cities. No negative externalities $(0 \%)$ were identified for the subsequent professional prospects.

- Attribution: 5\% for each outcome, because other agents contribute to the occurrence of these effects (for instance the family).

- Drop off: $10 \%$ because the effects considered last over time in a stable manner, except for future prospects, which are random and dependent on factors that cannot be controlled (50\%).

\section{A.4. Under-15 Players}

\section{A.4.1. Description}

Young athletes are certainly the privileged stakeholders for investigating the psychological impact of sporting activity on well-being. Together with their families, they are the direct recipients of educational activity and of the athletic training imparted by the coaches. In fact, the team environment is where they belong and becomes for them a kind of "educating community". A questionnaire was designed for them, aimed at investigating, on the one hand, the average expenditure they incur yearly incur to be able to train and to play home and away matches; on the other hand, to understand which aspects of their personalities are affected by the practice of a team sport.

The outcomes measured through financial proxies are the following:

- $\quad$ Self esteem

- Social skills

- Responsibility, time/stress management

\section{A.4.2. Positive Externalities and Outcomes}

The answers provided show that $75 \%$ of young athletes experienced impacts that are to be ascribed to Virtus Entella Football Team. The estimated duration of the effect is five years because the experience of practicing sport during growth produces positive effects on character formation that last over time. 


\section{A.4.3. Negative Externalities and Impacts}

- Deadweight: $10 \%$, because we considered that part of the outcomes would have been obtained even without the activities of the football club;

- Displacement: $10 \%$ due to any dysfunctional dynamics that could be created at the peer group level, especially in a competitive environment and that manifest outside the sport activity.

- Attribution: $20 \%$ for the "self-esteem" outcome, as it is presumed to be linked above all to other factors such as family relationships, friendships, academic achievement, etc.; with regard to the other outcomes, the percentage was set at $10 \%$ because there are other agents that could contribute to the occurrence of these effects.

- Drop off: $50 \%$, because the benefits gained can be affected by future experiences and changes in the existential conditions.

\section{A.5. Youth Sector Coaches}

\section{A.5.1. Description}

The coach, even when he is not aware of it, is an educator. Correcting and suggesting solutions while carrying out the exercises promotes the sensory and motor development of people. It also affects the whole personality, especially the potential for integration and emotional maturity. Coaches convey rules, values and the ethical dimension of sports: nowadays, as sports spread out and the average age of athletes has lowered down, there is an increasing need for meaningful human relationships and models in sport activities. The role of educator also comprises the ability to promote inclusive participation in sports, helping young athletes to make positive choices, understanding their emotions and social interactions, defusing conflicts in the team, organizing and orienting the team towards a constructive accomplishment of competitive tasks.

As for the Under-15 category, a short questionnaire (five items on the Likert scale) was developed in order to investigate the extent to which every professional thinks the educational aspect is important in the job.

The two areas investigated are the following:

- Change of educational capacity

- Change of the relationship between the company and families

\section{A.5.2. Positive Externalities and Outcomes}

Data collected show that $90 \%$ of the coaches of the different younger teams of Virtus Entella have found an impact that they ascribed to the activity of Virtus Entella. The estimated duration of the effect is five years for the acquisition of relational and educational skills and a year for the educational alliance established between the Company and the families of members during the championship.

\section{A.5.3. Negative Externalities and Impacts}

- Deadweight: 10\%, because we considered that part of the outcomes would have been obtained even without the activities of the football club.

- Displacement: $10 \%$ due to the stress stemming from the professional role held (responsibility, interpersonal dynamics, etc.) that may manifest in other life contexts of young players' lives.

- Attribution: $0 \%$ because there are no other agents that could contribute to the occurrence of these effects.

- Drop off: $10 \%$, because we presumed that the acquired relational and educational skills remain an experiential baggage of the educator. 


\section{A.6. Families}

\section{A.6.1. Description}

In team sports, the coach is part of a "Relational Triangle" which involves three figures: athletes, coach and parents. For families, the coach is a reference that may help them better understand their children and gain more knowledge about them. The coach is therefore in between sport and educational experience. Therefore, he and the young athletes' families are better off when cooperating and communicating with clarity and objectivity. It is essential that these two role models for the youngters support them in their training and path of growth, according to their own role.

The questionnaires elaborated for the families of young athletes are designed to identify the reasons that brought families to enroll their children in a soccer team. Using as usual Likert scales, the interviewed subjects indicated the extent to which they consider this experience to be educational, based on different variables, such as the value for health, respect for the rules, positive interaction with other people, character formation, taking responsibility and self-government.

The outcomes identified and monetized through financial proxies were grouped into thematic clusters:

- Physical exercise/group outdoor sports activity (for their children)

- Health education

- Affective-emotional education (tolerance to frustrations, stress management)

\section{A.6.2. Positive Externalities and Outcomes}

The analysis of available data shows that $80 \%$ of the families of young athletes experienced a positive impact due to the activity of Virtus Entella. The estimated duration of the effect is five years for the health education and affective-emotional education as they protract over time, whereas the duration of the possibility for their children to practice an outdoor team sport is limited to the duration of the championship.

\section{A.6.3. Negative Externalities and Impacts}

- Deadweight: $10 \%$, because we considered that part of the outcomes would have been obtained even without the activity linked to the Company.

- Displacement: $5 \%$ in relation to the amount of a different quality time they could have spent by undertaking other activities.

- Attribution: $0 \%$ for each outcome, because no other agent contributes to the occurrence of these effects.

- Drop off: $0 \%$ for the first outcome (because it is only related to one year) and equal to $50 \%$ for the other two psycho-social outcomes.

\section{A.7. Trust-Technical Sponsor}

\section{A.7.1. Description}

The "trust" variable was also considered, through a proxy developed considering the renewal of sponsorship contracts. It should be noticed that, despite the relegation to the Football League Third Division ("Serie C"), the sponsor confirmed the contract as if the company still played in the Second Division ("Serie B"), considering a set of values that the company cultivates and spreads that are in line and coherent with the corporate social responsibility included in the company's strategy. 


\section{A.7.2. Positive Externalities and Outcomes}

The partnership with the technical sponsor of the team, signed in the summer of 2018, highlights the attractiveness that the company can guarantee, being considered interesting by world-class brands. The proxy used for the outcome refers to the fees from sponsorships in the 2017/2018 season.

\section{A.7.3. Negative Externalities and Impacts}

In this case, as regards negative externalities, or externalities that can be attributed to other interacting variables, no percentage of reduction or mitigation over time was applied. The duration of impact that was considered was only one year.

\section{A.8. Municipality of Chiavari-Marina of Chiavari (Port of Chiavari City)}

\section{A.8.1. Description}

An analysis was carried out to measure how much Virtus Entella football club contributed to the visibility of Chiavari city's image and fame. Competing in a national league championship, with coverage from mass-media, has certainly spread the image of the city throughout the country. This outcome can only be achieved through different advertising channels on television, newspapers, magazines, social networks, online newspapers and other "social" channels on the Internet.

\section{A.8.2. Positive Externalities and Outcomes}

Positive externalities were considered, such as the reputation and image enhancement, calculated by using the cost of an advertisement campaign as a proxy.

\section{A.8.3. Negative Externalities and Impacts}

- Deadweight: $0 \%$ because without the team playing in the second division, this opportunity would not have been possible.

- Displacement: $0 \%$, as it is not considered that this could have negative effects on the community;

- Attribution: $40 \%$ consistent percentage because the merit of having contributed to the improvement of the image of the city of Chiavari is not only ascribable to Virtus Entella.

- Drop off: $5 \%$ because we considered that the positive effect and popularity will diminish over time.

\section{A.9. Duferco Group}

\section{A.9.1. Description}

The contribution of the group corporate sponsorship was also analyzed. The main outcomes identified are:

- Improved image of Duferco Group.

- Profit from further contracts for the supply of electricity and gas and other contracts in the Municipality of Chiavari and surrounding areas.

\section{A.9.2. Positive Externalities and Outcomes}

The proxies used estimated how much the presence of the "Duferco" brand in the football club's matches and other initiatives has actively contributed to the widespread visibility of the company and, to a lesser extent, also to the company's business.

\section{A.9.3. Negative Externalities and Impacts}

- Deadweight: $0 \%$ because without the team playing in the second division, this opportunity would not have been possible. 
- Displacement: $10 \%$, as it is considered a significant increase in emissions due to the greater number of customers and, therefore, to the corresponding consumption relative to the increased energy and gas production (e.g., $\mathrm{CO} 2, \mathrm{NOx}$, etc.).

- Attribution: 5\% for each outcome, as the improvement of the image and diffusion of the brand is undoubtedly due to other factors and advertising campaigns.

- Drop off: $5 \%$, because in the case of multi-year effects it must be considered that over time the positive effect tends to decrease exponentially.

\section{A.10. Philanthropic Activities-“Entella nel Cuore"}

\section{A.10.1. Description}

The activities of Entella nel Cuore were born out of solidarity and developed directly from Virtus Entella and ACD Entella's (Football Association) vocation of territory social development. These activities have grown together with the visibility and the structure of the company and, when the fundraisers reached significant sums of money, a special non-profit organization was created with the aim of gathering the contributions collected, thus avoiding the philanthropy's cash flows being mixed with those of sporting and commercial activities.

Because the sport and philanthropic activities work closely together, it was consistent with the systemic assessment of the team's impact, to consider also the philanthropic activities carried out by "Entella nel Cuore". At the same time, a sensitivity analysis was carried out in order to evaluate solely the activities of the team, without the philanthropic ones, to measure solely their impact, that resulted to be a positive one.

The association was created out of the need to manage with transparency the solidarity funds, but the spirit below the actions undertaken comes from the same management values of Virtus Entella. This transition took place in 2016 by the foundation of "Entella nel Cuore".

The aims of the association are:

1. Education

2. Citizenship

3. Solidarity

The three purposes converge in varying degrees for several initiatives. "Entella nel Cuore" represents an absolute novelty in the Ligurian soccer scene and carries out a noteworthy capillary work on the territory, without losing sight of the numerous national and international objectives.

With reference to the "educational activities", we assessed:

\section{A.10.2. Positive Externalities and Outcomes}

The duration of the psychological effects was assumed to last over time (5 years) while the economic effects have an annual duration.

\section{A.10.3. Negative Externalities and Impacts}

- Deadweight: $5 \%$ for students, because they are subject to other educational actions; $0 \%$ for the residents, as the outcomes achieved are dependent on the activity of the promoting association.

- Displacement: $0 \%$, as it is not considered that these activities could have any negative effects on the community.

- Attribution: $10 \%$ for students because there might be other agents contributing to the occurrence of these effects; $0 \%$ for the residents.

- Drop off: $10 \%$ for school students, considering a progressive reduction in the impact of what has been learned.

With reference to "citizenship", we assessed: 


\section{A.10.4. Positive Externalities and Outcomes}

The philanthropic association "Entella nel Cuore" organizes several activities for local community

\section{A.10.5. Negative Externalities and Impacts}

- Deadweight: $5 \%$, as there could be other similar services with the same purpose and structure;

- Displacement: $0 \%$, as it is not considered that these activities could have any negative effects on the community.

- Attribution: $70 \%$, because it is not possible to attribute a linked industry of such magnitude exclusively to the use of the "Chiavarinrete" service, which gathers many local activities and events.

- Drop off: $0 \%$ as the duration of the effects only lasts one year.

In reference to "solidarity activities", we assessed:

\section{A.10.6. Positive Externalities and Outcomes}

- Increase of health services

- Improvement of emotional and psychological condition

- Improvement of the health condition and quality of the hospital stay

\section{A.10.7. Negative Externalities and Impacts}

- Deadweight: $5 \%$ as there could be other similar services with the same purpose (improving the well-being and quality of life of small patients and family members).

- Displacement: $0 \%$, because no negative effects related to these activities were identified.

- Attribution: $30 \%$, because other factors external to the association's activity were identified that can contribute to the same results.

- Drop off: $0 \%$ as the duration of the effects lasts only one year.

\section{References}

1. Tripathi, A.; Bains, A. Evolution of corporate social responsibility: A journey from 1700BC till 21st century. Int. J. Adv. Res. 2013, 1, 788-796.

2. Carroll, A.B. Corporate Social Responsibility. Bus. Soc. 1999, 38, 268-295. [CrossRef]

3. Garriga, E.; Melé, D. Corporate Social Responsibility Theories: Mapping the Territory. J. Bus. Ethics 2004, 53, 51-71. [CrossRef]

4. Lin, W.; Ho, J.; Sambasivan, M. Impact of Corporate Political Activity on the Relationship Between Corporate Social Responsibility and Financial Performance: A Dynamic Panel Data Approach. Sustainability 2018, 11, 60. [CrossRef]

5. Hategan, C.-D.; Sirghi, N.; Curea-Pitorac, R.-I.; Hategan, V.-P. Doing Well or Doing Good: The Relationship between Corporate Social Responsibility and Profit in Romanian Companies. Sustainability 2018, 10, 1041. [CrossRef]

6. Simionescu, L.; Dumitrescu, D. Empirical Study towards Corporate Social Responsibility Practices and Company Financial Performance. Evidence for Companies Listed on the Bucharest Stock Exchange. Sustainability 2018, 10, 3141. [CrossRef]

7. Choi, J.; Kim, S.; Yang, D.-H. Small and Medium Enterprises and the Relation between Social Performance and Financial Performance: Empirical Evidence from Korea. Sustainability 2018, 10, 1816. [CrossRef]

8. Ángel Del Brío, J.; Lizarzaburu Bolaños, E. CSR Actions in Companies and Perception of Their Reputation by Managers: Analysis in the Rural Area of an Emerging Country in the Banking Sector. Sustainability 2018, 10, 920. [CrossRef]

9. Mulgan, G. Measuring Social Value. 2010. Available online: https://ssir.org/pdf/2010SU-Feature_Mulgan.pdf (accessed on 15 June 2019). 
10. Aaronson, S.A.; Reeves, J.T.; James, T.; National Policy Association (U.S.). Corporate Responsibility in the Global Village: The Role of Public Policy; National Policy Association: Washington, DC, USA, 2002; ISBN 0890681619. Available online: https://catalogue.nla.gov.au/Record/2480189 (accessed on 30 June 2019).

11. Watson, K.J.; Whitley, T. Applying Social Return on Investment (SROI) to the built environment. Build. Res. Inf. 2017, 45, 875-891. [CrossRef]

12. Associazione Sportiva Roma. Bilancio d'Impatto AS ROMA. 2016. Available online: https://res.cloudinary.com/asroma2-production/raw/upload/asroma2-prod/assets/as-roma-bilancioimpatto-2016-v-0-6-online.pdf (accessed on 20 June 2019).

13. Union of Europan Football Associations (UEFA). European Football United. UEFA direct. 2019. Available online: http://uefadirect.uefa.com/183/en/1-1/ (accessed on 28 June 2019).

14. Vernimmen, P. Corporate Finance: Theory and Practice; Wiley: Chichester, UK, 2011; ISBN 9781119975588.

15. Carande-Kulis, V.G.; Getzen, T.E.; Thacker, S.B. Public goods and externalities: A research agenda for public health economics. J. Public Health Manag. Pract. 2007, 13, 227-232. [CrossRef] [PubMed]

16. Laffont, J.-J. Externalities. In Allocation, Information and Markets; Palgrave Macmillan: London, UK, 1989; pp. 112-116.

17. Papandreou, A.A. Externality and Institutions; Clarendon Press: New York, NY, USA, 1998; ISBN 0198293070.

18. Pigou, A.C. The Economics of Welfare. Econ. J. 1933, 43, 329. [CrossRef]

19. Coase, R.H. The Problem of Social Cost. In Classic Papers in Natural Resource Economics; Palgrave Macmillan: London, UK, 1960; pp. 87-137.

20. Harvey, J. Externalities and Cost-benefit Analysis. In Economics Revision Guide; Macmillan Education: London, UK, 1994; pp. 62-64.

21. Livermore, M.A.; Revesz, R.L. The Globalization of Cost-Benefit Analysis in Environmental Policy; Oxford University Press: Oxford, UK, 2013; ISBN 9780199934386.

22. Glasson, J.; Therivel, R.; Chadwick, A. Introduction To Environmental Impact Assessment; Routledge: New York, NY, USA, 2013; ISBN 9781315881218.

23. Nicholls, J.; Cupitt, S.; Great Britain. Office of the Third Sector. A Guide to Social Return on Investment. 2009. Available online: http://www.socialvalueuk.org/resources/sroi-guide/ (accessed on 10 March 2019).

24. Vogel, I. Review of the Use of "Theory of Change" in International Development. 2012. Available online: http://www.theoryofchange.org/pdf/DFID_ToC_Review_VogelV7.pdf (accessed on 20 May 2019).

25. Rogers, P. Theory of Change: Methodological Briefs-Impact Evaluation No. 2; UNICEF Office of Research: Florence, Italy, 2014.

26. Emerson, J.; Twersky, F. New Social Entrepreneurs: The Success, Challenge and Lessons of Non-Profit Enterprise Creation; The Roberts Foundation Homeless Economic Fund: San Francisco, CA, USA, 1996.

27. Emerson, J.; Wachowicz, J.; Chun, S. Social Return on Investment: Exploring Aspects of Value Creation in the Nonprofit Sector; Roberts Foundation: San Francisco, CA, USA, 2000; Volume 2.

28. Einarsson, T.; Wijkström, F. Satellite Account on Nonprofit and Related Institutions and Volunteer Work. Nonprofit Policy Forum 2019, 10. Available online: https://www.degruyter.com/view/j/npf.2019.10.issue-1/npf2019-0011/npf-2019-0011.xml (accessed on 30 June 2019).

29. Salamon, L.M.; Sokolowski, W. The Size and Composition of the European Third Sector. In The Third Sector as a Renewable Resource for Europe; Palgrave Macmillan: Cham, Switzerland, 2018; pp. 49-94.

30. Nicholls, J.; Aeron-Thomas, D.; Forster, S.; Westall, A. Social Return on Investment: Valuing What Matters. 2004. Available online: https:/www.nefconsulting.com/wp-content/uploads/2017/09/sroi-valuing-whatmatters.pdf (accessed on 12 May 2019).

31. Arvidon, M.; Lyon, F.; McKay, S.; Moro, D. The Ambitions and Challenges of SROI (Social Return on Investment); University of Birmingham: Birmingham, UK, 2010.

32. Cooney, K.; Lynch-Cerullo, K. Measuring the Social Returns of Nonprofits and Social Enterprises: The Promise and Perils of the SROI. Nonprofit Policy Forum 2014, 5, 367-393. [CrossRef]

33. Millar, R.; Hall, K. Social Return on Investment (SROI) and Performance Measurement. Public Manag. Rev. 2013, 15, 923-941. [CrossRef]

34. Nicholls, J.; Lawlor, E.; Neitzert, E.; Goodspeed, T. A Guide to Social Return on Investment (SROI) (Revised). 2012. Available online: http://www.socialvalueuk.org/app/uploads/2016/03/The\%20Guide\%20to\%20Social\% 20Return\%20on\%20Investment\%202015.pdf (accessed on 15 March 2019). 
35. Perrini, F.; Vurro, C. La Valutazione Degli Impatti Sociali: Approcci e Strumenti Applicativi; EGEA: Milan, Italy, 2013; ISBN 8823843731. Available online: https://www.ibs.it/valutazione-degli-impatti-sociali-approccilibro-francesco-perrini-claudio-vurro/e/9788823843738 (accessed on 30 June 2019).

36. Layard, R.; Glaister, S. Cost-Benefit Analysis; Cambridge University Press: Cambridge, UK, 1994; ISBN 0521466741.

37. Arvidson, M.; Lyon, F.; McKay, S.; Moro, D. Valuing the social? The nature and controversies of measuring social return on investment (SROI). Volunt. Sect. Rev. 2013, 4, 3-18. [CrossRef]

38. Department of Health. Measuring Social Value. How Five Social Enterprises Did it. 2010. Available online: http://www.socialvalueuk.org/app/uploads/2016/06/dh_122354.pdf (accessed on 10 March 2019).

39. Jones, M. The Social Value of a Community-Based Health Project. 2012. Available online: http://eprints.uwe. ac.uk/16589/14/Jones_2012_HLW_Social_Value_Report_.pdf (accessed on 26 June 2019).

40. Ambrosini, M.T.; De Simone, G. Fuoriclasse: Un Modello di Successo per il Contrasto alla Dispersione Scolastica | Save the Children Italia. 2015. Available online: https:/www.savethechildren.it/sites/default/files/ files/uploads/pubblicazioni/fuoriclasse-un-modello-di-successo-il-contrasto-alla-dispersione-scolastica. pdf (accessed on 30 June 2019).

41. Ernst \& Young. Social Return on Investment of Tasmanian Youth Justice Programs. Save the Children Australia. 2015. Available online: http://www.socialvalueuk.org/app/uploads/2016/03/SCA_Youth-JusticeTAS_SROI_FINAL5b25d.pdf (accessed on 30 June 2019).

42. Viganò, F.; Lombardo, G. L'impatto sociale generato dai musei. L'applicazione della metodologia SROI. In Ambienti Digitali per L'educazione All'arte e al Patrimonio; Luigini, A., Panciroli, C., Eds.; FrancoAngeli Edizioni: Bolzano, Italy, 2018; ISBN 9788891773333.

43. Lombardo, G.; Vigano, F. Calculating the Social Impact of Culture. A SROI Application in a Museum. In Proceedings of the 1st International and Interdisciplinary Conference on Digital Environments for Education, Arts and Heritage; Luigini, A., Ed.; Springer International Publishing: Bolzano, Italy, 2019; pp. 1-10. ISBN 9783030122393.

44. Bottero, M.; Comino, E.; Dell'Anna, F.; Dominici, L.; Rosso, M.; Bottero, M.; Comino, E.; Dell'Anna, F.; Dominici, L.; Rosso, M. Strategic Assessment and Economic Evaluation: The Case Study of Yanzhou Island (China). Sustainability 2019, 11, 1076. [CrossRef]

45. Leck, C. Social Return on Investment (SROI) Evaluation Report, The Houghton Project. 2012. Available online: http://www.socialvalueuk.org/app/uploads/2016/03/Houghton\%20Project\%20SROI\%20assured.pdf (accessed on 30 June 2019).

46. Greenspace Scotland. Social Return on Investment (SROI) Analysis of the Greenlink, a Partnership Project Managed by the Central Scotland Forest Trust (CSFT). 2009. Available online: http://1068899683.n263075.test.prositehosting.co.uk/wp-content/uploads/2013/04/Greenlink-SROIFinal-report-5-October-2009.pdf (accessed on 30 June 2019).

47. Solórzano-García, M.; Navío-Marco, J.; Ruiz-Gómez, L.; Solórzano-García, M.; Navío-Marco, J.; Ruiz-Gómez, L.M. Ambiguity in the Attribution of Social Impact: A Study of the Difficulties of Calculating Filter Coefficients in the SROI Method. Sustainability 2019, 11, 386. [CrossRef]

48. Serie B-Supporters. Available online: https://www.transfermarkt.it/serie-b/besucherzahlen/wettbewerb/ IT2/plus/?saison_id=2017 (accessed on 28 June 2019).

49. Sibthorp, J.; Arthur-Banning, S. Developing Life Effectiveness through Adventure Education: The Roles of Participant Expectations, Perceptions of Empowerment, and Learning Relevance. J. Exp. Educ. 2004, 27, 32-50. [CrossRef]

50. Frauman, E.; Waryold, D. An Exploratory Study of the Impact of a Wilderness Orientation Program on College Student's Life Effectiveness. J. Outdoor Recreat. Educ. Leadersh. 2009, 1. [CrossRef]

(C) 2019 by the authors. Licensee MDPI, Basel, Switzerland. This article is an open access article distributed under the terms and conditions of the Creative Commons Attribution (CC BY) license (http://creativecommons.org/licenses/by/4.0/). 